\title{
PENGARUH MODEL PEMBELAJARAN KOOPERATIF TIPE THINK PAIR SHARE (TPS) TERHADAP HASIL BELAJAR \\ LAGU NUSANTARA SISWA KELAS VIII-I SMP YP PEMBANGUNAN GALANG
}

\author{
Sahat Maruli Siahaan \\ Prodi Pendidikan Musik
}

\begin{abstract}
This study aimed to determine the effect of student learning outcomes by applying the learning model Think Pair Share (TPS) on the archipelago song class VIII-I in SMP YP Pembangunan Galang of the Academic Year 2016/2017.

This type of research is True experimental design with pretest-Psottest Control Group Design. The population in the study were all second semester VIII class consisting of 3 classes. Sampling was done by random sampling. Sample chosen is a class VIII-I as the experimental class learning model Think Pair Share, amounting to 30 people and VIII-II as a control group with conventional learning models which amounted to 32 people. The instrument used in this study used multiple-choice test of 25 questions with four possible answers that have validator. The statistics are used to test the hypothesis of this study is to test $t$, As a prerequisite test used to test the normality and homogeneity.

Based on the post-test and analysis of data obtained an average value of 78.26 experimental group and the average value of the control group 66. From the results of hypothesis testing, it turns out the alternative hypothesis $(\mathrm{Ha})$ is accepted. Testing the hypothesis in research using hypothesis testing t-test two parties and of the calculation of the statistics obtained by value $t$ $=4.60 t$ the next price compared to the price ttabel with significance level of 5\% was obtained table $=2.0$ then $t \geq t$ table or $-t \leq-t$ table is $\geq 2.0$ or $-4.604 .60 \leq-2.0$. Then the results of testing hypothesis Ho is rejected and Ha is accepted.

Based on data analysis and discussion of the results of hypothesis testing, the conclusion of this study was no significant difference in the use of learning model Think Pair Share (TPS) to the learning outcomes obtained by students on track archipelago VIII-I in SMP YP Pembangunan Galang of the Academic Year 2016/2017.
\end{abstract}

Keywords: True Experiment, Think Pair Share, Learning Outcomes. 


\section{PENDAHULUAN}

Pendidikan merupakan
bagian terpenting dalam
terbentuknya suatu negara yang
makmur, Indonesia sendiri
berpedoman pada hal ini. Indonesia
adalah salah satu negara yang
memiliki sumber daya alam yang
melimpah, akan tetapi kekayaan
alam tersebut tidak akan bermakna
jika tidak dikelola dengan baik.
Untuk itu diperlukan sumber daya
manusia yang baik pula untuk dapat
mengelola kekayaan alam
tadi.Pendidikan memegang peranan

yang sangat penting untuk

mengembangkan sumber daya

manusia (SDM) yang berkualitas,

cerdas dan mampu bersaing.

Pendidikan dapat mewujudkan

semua potensi diri baik sebagai

pribadi maupun sebagai warga

masyarakat. Dalam mewujudkan potensi diri tersebut harus melewati sebuah proses pendidikan yang diimplementasikan dalam proses pembelajaran. Dalam konteks pembelajaran, siswa dianggap sebagai salah satu individu yang dituntut aktif dalam memahami dan mendalami pengetahuan yang di dapat dalam proses pembelajaran serta mampu mentransfer apa yang dipelajari ke dalam pengalaman kehidupan sehari-hari.

Proses belajar yang dilakukan secara formal di sekolah bertujuan untuk mengarahkan perubahan pada diri seorang siswa secara terencana baik dalam aspek pengetahuan, keterampilan dan sikap. Dunia pendi dikan saat ini ditandai dengan adanya perbedaan antara pencapaian akademik dan pencapaian praktik. Namun ada sebuah alasan yang lebih kokoh bahwasannya antara 
pencapaian akademik dan pengalaman yang menyenangkan pencapaian praktik haruslah sehingga siswa dapat merasakan diseimbangkan. Sejalan dengan laju bahwa musik itu merupakan sumber perkembangan dan perubahan yang keindahan.

mempengaruhi bidang pendidikan maka dibutuhkan tenaga pendidik yang profesional yang dapat menjalankan proses belajar mengajar sesuai dengan standar yang ada.

Pembelajaran seni musik pada pendidikan formal di Indonesia saat ini meliputi semua jenjang pendidikan mulai dari TK, SD, SMP, SMA/SMK. Pembelajaran seni musik memiliki kharakteristik sendiri yang membedakannya dengan mata pelajaran yang lain karena pembelajaran seni musik mengkaji hal-hal yang bersifat estetik melalui kegiatan berekspresi seperti bernyanyi dan bermain musik. Pembelajaran musik di sekolah harus menghantarkan siswa pada salah satu materi pembelajaran seni musik kelas VIII di SMP YP Pembangunan Galang. Lagu Nusantara adalah lagu yang berkembang diseluruh wilayah kepulauan Indonesia dan merupakan kebiasaan turun temurun yang masih dijalankan oleh masyarakat. Lagu Nusantara mendeskripsikan tentang ekspresi dan apresiasi. Secara khusus peneliti lebih merincikan kedalam apresiasi yaitu mendeskripsikan jenis lagu nusantara. Kurangnya minat siswa untuk belajar musik karena peserta didik hanya diberikan materi tentang lagu Nusantara dengan cara menjelaskan saja dan hanya menuntut siswa untuk 
mendengar dan menghafal materi tanpa dipraktekkan oleh guru. Hal ini menyebabkan peserta didik merasa bosan dan kurang mendapatkan prestasi yang baik dalam pembelajaran. Selain hal tersebut media pembelajaran juga sangat mempengaruhi siswa dalam pembelajaran seni musik, guru tidak menerapkan media pembelajaran seperti gitar, pianika, keyboard didalam proses pembelajaran sehingga pembelajaran dikelas terkesan tidak menarik. Dari hasil observasi dengan guru bidang studi seni budaya Ibu Honnery Saragih, sekitar $40 \%$ siswa yang mengikuti ujian mid semester mendapatkan nilai rata-rata yang memenuhi nilai Kriteria Ketuntasan Minimum (KKM) dengan nilai 70, selebihnya siswa harus mengikuti remedial dengan nilai di bawah KKM. Hal ini disebabkan guru menggunakan model pembelajaran yang kurang tepat yaitu model pembelajaran konvensional. Model Pembelajaran konvensional merupakan model pembelajaran dimana kegiatan yang dilakukan adalah kegiatan secara umum. Siswa hanya mendengar, melihat, menerima, mencatat dan me ngerjakan materi pelajaran dan guru hanya memberikan materi pelajaran dalam bentuk interaksi penjelasan, penuturan lisan, bertanya kepada beberapa siswa namun siswa tidak merasa terlibat didalamnya.

Dengan adanya masalah diatas maka peneliti ingin mencoba membuat eksperimen dengan menggunakan model pembelajaran Kooperatif Tipe Think, Pair, Share (TPS) dalam pembelajaran Lagu Nusantara, untuk melihat apakah ada hasil yang signifikan terhadap hasil 
belajar Lagu Nusantara di SMP YP Pembangunan Galang. Model pembelajaran kooperatif tipe TPS ini mengkondisikan siswa untuk aktif dan saling memberi dukungan dalam kerja kelompok untuk menuntaskan materi masalah dalam belajar. Model pembelajaran Think, Pair, Share (TPS) merupakan suatu model pembelajaran kooperatif yang memberi siswa waktu untuk berpikir dan merespon serta saling bantu satu sama lain. Selain dapat bekerja secara berkelompok, guru juga dapat memastikan tanggung jawab masingmasing individu dengan cara memberikan peran atau tugas kepada setiap individu. Selanjutnya, siswa akan mempresentasikan atau menampilkan hasil kreasi kelompok mereka di hadapan siswa lain. Berdasarkan latar belakang masalah yang telah diuraikan maka peneliti merumuskannya ke dalam sebuh judul "Pengaruh Model

\section{Pembelajaran Koopertif Tipe}

Think Pair Share (TPS) Terhadap

Hasil Belajar Lagu Nusantara

Siswa Kelas VIII-I SMP YP

Pembangunan Galang”.

\section{Tujuan Penelitian}

1. Untuk mengetahui pengaruh model pembelajaran Think Pair Share (TPS) terhadap hasil belajar siswa kelas VIIII pada materi Lagu Nusantara di SMP YP Pembangunan Galang.

2. Untuk mengetahui hasil belajar siswa setelah menggunakan model pembelajaran kooperatif tipe Think Pair Share (TPS) di kelas VIII-I SMP YP Pembangunan Galang. 


\section{Landasan Teoritis}

Untuk membahas tentang isi dalam skripsi ini penulis memakai Teori tentang Pengaruh model pembelajaran kooperatif tipe think pair share (TPS).

\section{Lokasi dan Waktu Penelitian}

Peneliti ini dilaksanakan di sekolah SMP YP Pembangunan Galang dan waktu Penelitian ini dilaksanakan dari bulan Januari 2017 sampai Maret 2017 pada semester genap tahun ajaran 2016/2017

\section{Populasi dan Sampel}

\section{Populasi}

Populasi dalam penelitian ini adalah seluruh siswa kelas VIII SMP YP Pembangunan Galang yg berjumlah 96 orang.

\section{Sampel}

Sampel dalam penelitian ini adalah siswa kelas VIII-I SMP YP
Pembangunan Galang yang

berjumlah 30 orang.

\section{Desain Penelitian}

Penelitian ini bersifat eksperimen, yaitu metode true eksperimen, dengan model PretestPsottest Kontrol Group Design.

\section{Teknik Pengumpulan Data}

1. Kisi-Kisi Instrument.

2. Instrument Penelitian

3. Uji Coba Instrument
a. Validitas isi
b. Reliabilitas Instrumen
c. Uji Indeks Kesukaran Tes
d. Uji Daya Pembeda Tes

4. Studi Kepustakaan

$$
\text { Pengumpulan data- data }
$$
berdasarkan skripsi, buku-buku yang digunakan penulis yang berkaitan dan mendukung penelitian. 


\section{Teknik Analisis Data}

Teknik pengumpulan data di atas diarahkan melalui analisis data kuantitatif. Teknik yang digunakan untuk memeriksa keabsahan data adalah dengan cara deskripsi data, uji normalitas, uji homogenitas, dan uji hipotesis.

\section{ISI}

\section{Analisis Data Instrumen Penelitian}

\section{a. Validitas tes}

Dalam uji validitas, dari 30 soal terdapat 25 soal yang valid dan 5 soal yang tidak valid (lampiran 4). Soal yang valid akan digunakan untuk Pretes dan Postes kelas eksperimen, untuk mengetahui data dan hasil akhir dari kelompok eksperimen dan kontrol.

\section{b. Reliabilitas Tes}

Suatu soal dikatakan reliabel jika $\quad r_{\text {hit }}>r_{\text {tab. Berdasarkan hasil }}$ penghitungan dengan menggunakan rumus KR-34 diperoleh harga $r_{\text {hit }}$ adalah 0,753 sedangkan $r_{\text {tab }}$ pada tabel product moment dengan taraf signifikan $5 \% \quad(\alpha=0,05)$ adalah 0,349 . Hal ini berarti bahwa $r_{\text {hit }}>r_{\text {tab }}$ yaitu $0,753>0,349$. Dengan demikian soal dinyatakan reliabel. (lampiran 5)

\section{c. Tingkat kesukaran soal}

Soal yang baik adalah soal yang tidak terlalu mudah atau tidak terlalu sukar atau soal tersebut tergolong dalam kategori sedang. Berdasarkan perhitungan tingkat kesukaran soal (lampiran 7 ), dari 30 butir soal diperoleh hasil sebagai berikut : 8 soal tergolong dalam kategori mudah, 21 soal tergolong 
dalam kategori sedang, dan 1 soal tergolong kategori sukar.

\section{d. Daya Pembeda Soal}

Daya pembeda soal merupakan kemampuan soal untuk membedakan siswa yang berkemampuan tinggi dengan siswa yang berkemampuan rendah. Berdasarkan perhitungan daya pembeda soal (lampiran 10), dari 30 butir soal diperoleh hasil sebagai berikut : 6 soal tergolong memiliki daya pembeda yang baik, 14 soal tergolong memiliki daya pembeda yang cukup, 10 soal tergolong memiliki daya pembeda soal yang jelek.

\section{Deskripsi Data Hasil Penelitian}

Sebelum kedua sampel diberikan perlakuan yang berbeda terlebih dahulu diberikan tes awal (pre-test) yang bertujuan untuk mengetahui kemampuan awal masing-masing siswa pada kedua kelas, serta untuk mengetahui kedua kelas terdistribusi normal dan homogen. Selanjutnya dilakukan pembelajaran yang berbeda yaitu kelas eksperimen dengan menggunakan model pembelajaran kooperatif tipe Think Pair Share (TPs) dan kelas kontrol dengan menggunakan model pembelajaran langsung. Pada akhir proses pembelajaran akan diberikan tes akhir (post-test) untuk mengetahui hasil belajar siswa setelah diberikan perlakuan.Berdasarkan hasil penelitian setelah dilakukan perhitungan maka diperoleh data pretest dan post-test kelas eksperimen dan kelas kontrol yang terdapat pada tabel 4.1 dan di bawah ini : 


\begin{tabular}{|c|c|c|c|c|c|c|}
\hline \multicolumn{4}{|c|}{$\begin{array}{l}\text { Data Nilai Pretest } \\
\text { Kelas Eksperimen }\end{array}$} & \multicolumn{3}{|c|}{$\begin{array}{c}\text { Data Nilai } \\
\text { Pretest Kelas } \\
\text { Kontrol }\end{array}$} \\
\hline $\begin{array}{l}\mathbf{N} \\
\mathbf{O}\end{array}$ & $\begin{array}{l}\text { Ni } \\
\text { lai }\end{array}$ & $\begin{array}{l}\text { Frek } \\
\text { uensi }\end{array}$ & $\begin{array}{l}\text { Ra } \\
\text { ta- } \\
\text { Ra } \\
\text { ta }\end{array}$ & $\begin{array}{l}\mathbf{N i} \\
\text { lai }\end{array}$ & $\begin{array}{l}\text { Frek } \\
\text { uensi }\end{array}$ & $\begin{array}{c}\text { Ra } \\
\text { ta- } \\
\text { rat } \\
\text { a }\end{array}$ \\
\hline 1 & 35 & 1 & \multirow{6}{*}{$\begin{array}{c}47 \\
2\end{array}$} & 34 & 3 & \multirow{6}{*}{$\begin{array}{c}45, \\
7\end{array}$} \\
\hline 2 & 42 & 12 & & 39 & 6 & \\
\hline 3 & 49 & 15 & & 44 & 7 & \\
\hline 4 & 56 & 1 & & 49 & 8 & \\
\hline 5 & 63 & 0 & & 54 & 7 & \\
\hline 6 & 70 & 1 & & 59 & 1 & \\
\hline
\end{tabular}

dilakukan perhitungan maka diperoleh data pre-test dan post-test kelas kontrol yang terdapat pada tabel 4.2 dan di bawah ini .

\begin{tabular}{|c|c|c|c|c|c|c|}
\hline \multicolumn{4}{|c|}{$\begin{array}{l}\text { Data Nilai Postest } \\
\text { kelas eksperiment }\end{array}$} & \multicolumn{3}{|c|}{$\begin{array}{c}\text { Data Nlai } \\
\text { posttest kelas } \\
\text { Kontrol }\end{array}$} \\
\hline $\begin{array}{l}\mathbf{N} \\
\mathbf{O}\end{array}$ & $\begin{array}{l}\mathrm{Ni} \\
\text { lai }\end{array}$ & $\begin{array}{l}\text { Frek } \\
\text { uensi }\end{array}$ & $\begin{array}{c}\text { Ra } \\
\text { ta- } \\
\text { rat } \\
\text { a }\end{array}$ & $\begin{array}{l}\text { Ni } \\
\text { lai }\end{array}$ & $\begin{array}{l}\text { Frek } \\
\text { uensi }\end{array}$ & $\begin{array}{c}\text { Ra } \\
\text { ta- } \\
\text { rat } \\
\text { a }\end{array}$ \\
\hline 1 & 62 & 4 & \multirow{6}{*}{$\begin{array}{l}78, \\
26\end{array}$} & 58 & 10 & \multirow{6}{*}{$\begin{array}{l}66, \\
87\end{array}$} \\
\hline 2 & 67 & 1 & & 63 & 7 & \\
\hline 3 & 72 & 5 & & 68 & 5 & \\
\hline 4 & 77 & 2 & & 73 & 6 & \\
\hline 5 & 82 & 12 & & 78 & 3 & \\
\hline 6 & 87 & 3 & & 83 & 0 & \\
\hline 7 & 92 & 3 & & 88 & 1 & \\
\hline
\end{tabular}

\section{Analisis Data Hasil Penelitian}

Ringkasan Hasil Perhitungan Nilai Rata-rata, Standar Deviasi dan Varians.

\begin{tabular}{|l|c|c|c|}
\hline \multicolumn{2}{|c|}{ Keterangan } & Eksperimen & Kontrol \\
\hline Rata- & Pretest & 47,2 & 45,75 \\
\cline { 2 - 4 } rata & Postest & 78,26 & 66,87 \\
\hline $\begin{array}{l}\text { Stand } \\
\text { ar } \\
\text { Devia } \\
\text { si }\end{array}$ & Pretest & 7,15 & 6,17 \\
\cline { 3 - 4 } & Postest & 9,13 & 7,61 \\
\hline $\begin{array}{l}\text { Varia } \\
\text { ns }\end{array}$ & Pretest & 51,2 & 38,12 \\
\cline { 2 - 4 } & Postest & 83,51 & 58,04 \\
\hline
\end{tabular}

\section{a) Uji Normalitas Data}

Pengujian normalitas data pada penelitian ini menggunakan rumus lilifors. Berdasarkan data tabel 4.4 dapat dilihat bahwa $\mathrm{L}_{0}$ yang diperoleh lebih kecil dari $\mathrm{L}_{\text {tabel }}$ dengan taraf signifikan $\propto=0,05$, sehingga memenuhi data yaitu jika $\mathrm{L}_{0} \leq \mathrm{L}_{\text {tabel }}$. Dengan demikian dapat disimpulkan bahwa distribusi data 
pretest dan postest hasil belajar dengan menggunakan model pembelajaran Think Pair Share (TPS) dan dengan model pembelajaran langsung berdistribusi normal antara kedua kelas. Hal ini membuktikan bahwa data yang diperoleh memenuhi persyaratan uji normalitas untuk keperluan pengujian homogenitas data dan pengujian hipotesis.

\section{b) Uji Homogenitas Data}

Untuk menguji apakah sampel berasal dari populasi yang homogen digunakan uji kesamaan dua varian. Berdasarkan Tabel 4.5 hasil uji homogenitas untuk nilai pretes diperoleh harga $F_{\text {hitung }}=1,34$, sedangkan dari tabel nilai persentil untuk distribusi $\mathrm{F}$ dengan taraf nyata $\alpha=0,05$ dan $\mathrm{F}_{\text {tabel }}=1,84$ karena harga $F_{\text {hitung }}$ lebih kecil dibanding harga $\mathrm{F}_{\text {tabel }}(1,067<1,85)$, maka dapat disimpulkan bahwa hasil pretes hasil belajar siswa dari kedua kelas tersebut memiliki varian yang seragam (homogen)

Pada nilai postes diperoleh harga $F_{\text {hitung }}=1,43$ sedangkan dari tabel nilai persentil untuk distribusi $\mathrm{F}$ dengan taraf nyata $\alpha=0,05$ dan dan $\mathrm{F}_{\text {tabel }}=1,84$ karena harga $\mathrm{F}_{\text {hitung }}$ lebih kecil dibanding harga $\mathrm{F}_{\text {tabel }}(1,43<$ 1,84), maka dapat disimpulkan bahwa hasil pretes hasil belajar siswa dari kedua kelas tersebut memiliki varian yang seragam (homogen).

\section{c) Uji Hipotesis}

Setelah dilakukannya uji normalitas dan homogenitas, maka selanjutnya dilakukan uji hipotesis dengan uji t. Berdasarkan tabel di atas diperoleh $t_{\text {hitung }}=0,87$ dan $t_{\text {tabel }}=$ 1,67. Karena $t_{\text {hitung }}<t_{\text {tabel }}=0,87<$ 1,67, maka kemampuan awal siswa 
dalam pretest pada kedua kelompok

sampel adalah sama. Selanjutnya

diadakan Pengujian hipotesis

dengan uji t pada posttest.

Berdasarkan tabel 4.7

diperoleh $t_{\text {hitung }}=4,60$ dan $t_{\text {tabel }}=2,00$, dengan taraf siginifikan $0,05 \mathrm{dan} \mathrm{dk}$

$=60$. Karena $t_{\text {hitung }}>t_{\text {tabel }}=4,60>$ 2,00, maka $\mathrm{H}_{\mathrm{a}}$ diterima atau Ho ditolak. Dapat disimpulkan bahwa ada perbedaan yang signifikan dengan menggunakan model pembelajaran think pair share dibandingkan model pembelajaran konvensional terhadap hasil belajar siswa pada materi poko lagu nusantara kelas VIII-I SMP YP Pembangunan Galang.

\section{Pembahasan Hasil Penelitian}

Penelitian ini diawali dengan memberikan pretest terhadap kedua sampel dengan jumlah 25 soal dalam bentuk pilihan berganda dengan 4 pilihan. Hasil penelitian menunjukkan bahwa ada pengaruh penggunaan model pembelajaran kooperatif tipe Think Pair Share (TPS) terhadap hasil belajar siswa pada lagu Nusantara di kelas VIII-I SMP YP Pembangunan Galang. Hal ini diperkuat dengan perolehan nilai rata-rata pretes siswa dikelas eksperimen sebesar 47,2 dengan standar deviasi 7,15 serta varian 51,2 dan nilai rata-rata postes sebesar 78,26 dengan standart deviasi 9,13 dan varian 83,51 . Sedangkan dikelas kontrol diperoleh nilai rata-rata pretes siswa sebesar 45,75 dan standart deviasi 6,17 serta varian 38,12 dan nilai rata-rata postes sebesar adalah 66,87 standart deviasi 7,61 dan varian 58,04..

Dari hasil perhitungan diperoleh suatu kesimpulan bahwa 
kemampuan awal siswa kelas eksperimen dan kelas kontrol adalah homogen. Demikian pula untuk uji normalitas dan uji homogenitas, perolehan nilai hasil pretes dan postes untuk kelas eksperimen dan kontrol tersebut sudah normal dan homogen. Dari perhitungan data dengan menggunakan uji $\mathrm{f}$ pretes kelas eksperimen dan kelas kontrol dieroleh $F_{\text {hitung }}=1,34<F_{\text {tabel }} 1,84$, maka dapat disimpulkan nilai pretes kedua kelas sampel adalah homogen . Selanjutnya kedua kelas diberikan perlakuan yang berbeda, kemudian pada pertemuan terakhir diberikan postes dengan soal yang sama seperti soal pretes. Dengan menggunakan uji $\mathrm{F}$ diperoleh $\mathrm{F}_{\text {hitung }}=1,43<\mathrm{F}_{\text {tabel }}$ 1,84, maka dapat disimpulkan nilai postes kedua sampel adalah homogen.
Selanjutnya perhitungan data dengan menggunakan uji $\mathrm{t}$ pretes kelas eksperimen dan kontrol diperoleh $t_{\text {hitung }}<t_{\text {tabel }}(0,87<$ 1,67 ) maka kemampuan awal siswa pada kelas eksperimen sama dengan kemampuan awal siswa pada kelas kontrol. Tahap selanjutnya kedua kelas diberikan perlakuan yang berbeda, dan kedua kelas diberikan postes dengan menggunakan uji t dan diperoleh $t_{\text {hitung }}>t_{\text {tabel }}(4,60>$ 2,00 ) maka $H_{o}$ ditolak dan $H_{a}$ diterima dengan kata lain bahwa ada pengaruh model pembelajaran kooperatif tipe TPS (Think Pair Share ) terhadap hasil belajar siswa pada Lagu Nusantara siswa kelas VIII-I SMP YP Pembangunan Galang. 
think pair share (TPS) dikelas

VIII-I SMP YP Pembangunan

Galang.

\section{PENUTUP}

\section{Kesimpulan}

Berdasarkan hasil penelitian yang diperoleh dari hasil analisa data dan pengujian hipotesis maka dapat disimpulkan sebagai berikut:

1. Ada Pengaruh model pembelajaran Kooperatif tipe Think Pair Share (TPS) terhadap hasil belajar siswa pada lagu nusantara kelas VIII-I SMP YP Pembangunan Galang. Dimana siswa lebih aktif lagi dan lebih cepat memahami materi yang diajarkan .

2. Hasil belajar siswa kelas eksperimen meningkat $17,03 \%$ setelah menggunakan model pembelajaran kooperatif tipe

\section{Saran}

Berdasarkan hasil dan kesimpulan dalam penelitian ini, maka peneliti mempunyai beberapa saran untuk memperbaiki kualitas hasil belajar siswa, antara lain:

1. Bagi para peneliti selanjutnya yang meneliti tentang model Think Pair Shareagar lebih baik dalam mengelola kelas agar situasi kelas lebih kondusif selama proses pembelajaran berlangsung.

2. Bagi guru diharapkan menggunakan model Think Pair Share sebagai salah satu alternatif dalam proses pembelajaran karena model dapat 
membuat siswa lebih aktif dalam

belajar sehingga dapat

meningkatkan hasil belajar

akademik siswa maupun sosial siswa.

\section{DAFTAR PUSTAKA}

Arikunto. 2010. Dasar-Dasar

Evaluasi Pendidikan. Bumi Akasara:

Jakarta.

Grafindo Media Pratama. 2008.

SeniBudaya: Bandung.

Harry Sulastianto, dkk. 2008. Seni

Budaya. Grafindo Media Pratama:

Bandung.

Isjoni. 2014. Cooperative Learning.

Alfabeta: Bandung.

Istarani. 2012. 58 Model

Pembelajaran Inovatif. Media

Persada: Medan.
Manurung. 2013.

StatistikPendidikan.HalamanMoeka.

Jakarta Barat

Miftahul.2014. Model-Model

Pengajaran dan Pembelajaran.

Pustaka Pelajar:



Yogyakarta.

Nikmah. 2013. Model Pembelajaran

Kooperatif Tipe Think Pair Share

(TPS) disertai Media CD Interaktif

Pada Pembelajaran Fisika di SMA

Negeri 1Kencong Jember. Jurnal

Pembelajaran Fisika. ISSN 2301-

9794

Roma. 2016. Pengaruh Model

Kooperatif Tipe Think Pair Share

(TPS) Berbantu Media Video

Pembelajaran Terhadap Hasil Belajar

dan sikap Siswa Pada Materi Sistem

Reproduksi Manusia di Kelas XI IPA

SMA Katolik $1 \quad$ Kabanjahe T.P

2015/2016. Skripsi Unimed Medan. 
Rusman. 2012. Model-Model

Pembelajaran. PT Raja Grafindo

Persada: Jakarta.

Shoimin. 2014. 68 Model

Pembelajaran Inovatif dalam

Kurikulum 2013. AR- Ruzz Media:

Yogyakarta.

Silitonga. 2013. Teori Musik.

Unimed Press. Medan

Slameto. 2010. Belajar dan Faktor F

aktor yang Mempengaruhinya. Rinek

a Cipta: Jakarta.

Slavin. 2009. Cooperative Learning.

Nusa Media: Bandung.

Sudijono. 2011. Pengantar Evaluasi

Hasil Belajar. PT Raja Grafindo

Persada: Jakarta.

Sudijono.PengantarStatistikaPendidi

kan.Grafindo. Jakarta
Sudjana. 2009. Metode Statistika.

Runeka Cipta: Jakarta.

Sudjana. 2009. Penilaian Hasil Pros

es Belajar Mengajar. PT Remaja Ros

dakary : Bandung.

Sugiyono. 2015.Metode Penelitian

Pendidikan. Alfabeta: Bandung.

Sugiyono. 2016.

StatistikaUntukPenelitian. Alfabeta.

Bandung

Suprijono. 2010. Cooperative

Learning. Pustaka Pelajar:

Yogyakarta.

Tim abdi Guru. 2007. Seni Budaya.

Erlangga: Demak.

Trianto. 2011. Mendesain Model

Pembelajaran Inovatif-Progresif.

Jakarta: Kencana Prenada Media

Group.

\section{Daftar Acuan Internet}


(Sumber:http://en.m.wikipedia.org/w

iki/Lagu_Nusantara)

(Sumber:http://id.m.wikipedia.org/wi

ki/think pair share) http://mgmpseni.wordpress.com/mate

ri-belajar/seni-musik/semester-

1/kelas-viii/lagu-nusantara/ 